Krzysztof Kwiecień

Koło Naukowe „Bibliolog”

Uniwersytet Pedagogiczny w Krakowie

\title{
Rola Wojewódzkiej Biblioteki Publicznej w Krakowie w aktywizacji osób starszych
}

Nie starzeje się ten, kto nie ma na to czasu

Benjamin Franklin (1706-1790)

\section{Wstęp}

Użytkownikami bibliotek publicznych w 56\% są osoby młode - dzieci, młodzież szkolna, studenci i dorośli do pięćdziesiątego roku życia. Natomiast pozostałe $44 \%$ to ludzie po pięćdziesiątym roku życia, tzw. seniorzy. Do tej grupy zaliczamy zarówno osoby aktywne zawodowo oraz osoby po osiemdziesiątce. Jak możemy zauważyć, między seniorami jest różnica w posiadanym doświadczeniu ponad jednego pokolenia ${ }^{1}$.

W 2009 roku, jako dodatek do „Poradnika Bibliotekarza” ukazały się dwa numery „Biblioteki dla Seniorów” będące źródłem ciekawych informacji i spostrzeżeń na temat aktywizacji osób starszych w bibliotekach. Trzeba jednak zwrócić uwage na to, że ta grupa społeczna od dawna jest związana z biblioteką publiczną, ale dopiero teraz tworzone są nowe usługi dostosowane do ich potrzeb ${ }^{2}$.

W naszym społeczeństwie funkcjonuje wiele stereotypów dotyczących seniorów np.: „Osoby starsze wymagają ciągłej opieki”, ,już niczego nowego się nie nauczą, nie powinni już oczekiwać nic od życia"3 oraz wiele innych. Te

\footnotetext{
${ }^{1}$ Skoczkowa E.: Koncepcja działań bibliotek publicznych na rzecz osób starszych $i$ niepetnosprawnych [online]. Dostępny w Internecie: http://www.znak.org.pl/biblioteka/?sciezka-seniorzy, 19 [data dostępu: 4.05.2012].

2 Dobrowolska M.: Seniorzy $w$ bibliotekach publicznych: poradnik. Warszawa: Wydawnictwo Stowarzyszenia Bibliotekarzy Polskich, 2012, s. 7-8.

3 Redakcja czas-seniora.pl. Stereotypy dotyczqce seniorów [online]. Dostępny w Internecie: http://www.czas-seniora.pl/?p=1596 [data dostępu: 4.05.2012].
} 
stereotypy mocno zakorzenione w naszym myśleniu chciałbym „obalić” prezentując działania na rzecz osób starszych w Wojewódzkiej Biblioteki Publicznej w Krakowie.

W Krakowie jest wiele miejsc i instytucji, które pomagają w aktywizacji osób starszych. Do nich zaliczamy Uniwersytety Trzeciego Wieku działające przy krakowskich uczelniach oraz kluby seniora. Oczywiście nie można tutaj pominąć roli bibliotek. Biblioteka to nie tylko miejsce dla ludzi młodych to miejsce dla wszystkich bez względu na wiek. Prawie „każda biblioteka może się pochwalić grupą osób starszych, będącymi regularnymi czytelnikami” ${ }^{4}$. Wojewódzka Biblioteka Publiczna w Krakowie wyszła naprzeciw osobom starszym realizując razem z Towarzystwem Polsko-Niemieckim program Szkoła @ktywnego Seniora. Jest to przykład unikalnej w skali Polski długoterminowej współpracy organizacji pozarządowej i instytucji kultury ${ }^{5}$.

\section{Początki działalności programu}

Szkoła@ktywnego Seniora to innowacyjny i autorski program skierowany do ludzi starszych. Pomysł na tego typu działalność powstał w 2007 roku, kiedy to Towarzystwo Polsko-Niemieckie, razem z Regionalnym Centrum Integracji Społecznej ${ }^{6}$ Wojewódzkiej Biblioteki Publicznej w Krakowie rozpoczęły realizację założeń tego programu. Potrzeba działań na rzecz seniorów w bibliotece wynikła z postępu technologicznego i pojawienia się wielu młodych użytkowników (głównie studentów). Te czynniki spowodowały spadek aktywności osób starszych w bibliotece. Konieczne były działania, które zachęciłyby seniorów do powrotu do biblioteki ${ }^{7}$.

Z inicjatywy byłego dyrektora Wojewódzkiej Biblioteki Publicznej w Krakowie, Artura Paszko, w 2006 roku powstało Regionalne Centrum Integracji Społecznej. Na początku działalności zajmowano się głównie mniejszościami narodowymi (Romowie), w późniejszym czasie zaczęto się skupiać również na integracji społecznej osób starszych. Celem było przede wszystkim „organizacja i zapewnienie zaplecza informacyjnego dla osób i grup zagrożonych wykluczeniem społecznym" ${ }^{\text {. }}$. Do takich grup, oprócz mniejszości

\footnotetext{
${ }^{4}$ Skoczkowa, E.: dz. cyt.

${ }^{5} \mathrm{Na}$ podstawie rozmowy przeprowadzonej z panią dr Lidią Marią Jedlińską, koordynatorem programu Szkoty @ktywnego Seniora w dniu 3.11.2011 r.

${ }^{6}$ Od 1 marca 2012 roku RCIS zostało włączone do nowego Działu Edukacji, Nauki i Badań Wojewódzkiej Biblioteki Publicznej w Krakowie.

${ }^{7}$ Tamże.

8 Woźniakiewicz J.: Regionalne Centrum Integracji Społecznej. Wojewódzka Biblioteka Publiczna w Krakowie [online]. Dostępny w Internecie: http://www.rajska. info/dla-czytelnikow/regionalne-centrum-integracji-spolecznej.html [data dostępu: 4.05.2012].
} 
narodowych i etnicznych, należą również osoby niepełnosprawne, imigranci i seniorzy ${ }^{9}$. Regionalne Centrum Integracji Społecznej zbierało informacje o grupach, pomagało im w kwestiach prawnych, realizowało projekty edukacyjne z zakresu tolerancji i polityki antydyskryminacyjnej. Oprócz pomocy, do zadań centrum należała również edukacja w kwestii integracji społecznej i popieranie postaw tolerancyjnych wobec inności ${ }^{10}$.

Od 2007 roku wspólnie z Towarzystwem Polsko-Niemieckim w Krakowie, Regionalne Centrum Integracji Społecznej zaczęło realizować program Szkoła@ktywnego Seniora ${ }^{11}$. Najpierw było to bezpłatne kursy komputerowe, mające na celu alfabetyzację cyfrową osób starszych. Z powodu dużego zainteresowania tego typu kursami, zaczęto organizować również inne bezpłatne zajęcia dla seniorów ${ }^{12}$.

\section{Opis programu}

Działalność Szkoły@ktywnego Seniora zorganizowana jest wokół trzech modułów: „ICT ${ }^{13}$ Senior $w$ świecie nowych technologii”, „Senior $w$ świecie kultury i sztuki”, „Senior świadomym i petnoprawnym obywatelem ${ }^{\prime 14}$.

Pierwszy moduł obejmuje zakres szkoleń dotyczących nowych technologii. Seniorzy aktywnie uczą się posługiwać komputerem i korzystać z Internetu. Zdobywają również wiedzę niezbędną w poruszaniu się po środowisku informacyjnym. Warto również zwrócić uwagę na sposób realizacji tego modułu - kursy prowadzone są przez młodych pracowników biblioteki. Nawiązuje się dzięki temu dialog międzypokoleniowy, niezbędny do sprawnej komunikacji między seniorami, a młodszymi generacjami. Poprzez zaangażowanie pracowników biblioteki rozwijany jest bardzo skutecznie wolontariat pracowniczy, dając młodym ludziom szansę na podniesienie swoich kwalifikacji i zapobiegający „,wypaleniu zawodowemu”" ${ }^{\text {.15 }}$ Założeniem modułu jest nie tylko nauka obsługi komputera i Internetu, ale również wykorzystanie tej

\footnotetext{
${ }^{9}$ Tamże.

${ }^{10}$ Tamże.

$11 \mathrm{Na}$ podstawie rozmowy przeprowadzonej z panią dr Lidią Marią Jedlińską, koordynatorem programu Szkoty @ktywnego Seniora w dniu 3.11.2011 r.

12 Tamże.

${ }^{13}$ Skrót od ,Information and communications technology."

14 Jedlińska L. M.: Biblioteki kreatorami przyszłości. Nowatorskie rozwiazania Wojewódzkiej Biblioteki Publicznej w Krakowie w stymulowaniu aktywności osób starszych. „Biuletyn EBIB” 2008, nr 7 (98) [dokument elektroniczny]. Dostępny w Internecie: http://www.ebib.info/2008/98/a.php?jedlinska [data dostępu: 4.05.2012].

${ }^{15} \mathrm{Na}$ podstawie rozmowy przeprowadzonej z panią dr Lidią Marią Jedlińską, koordynatorem programu Szkoły @ktywnego Seniora w dniu 3.11.2011 r.
} 
wiedzy w praktyce do rozwoju swoich zainteresowań (kontakt z rówieśnikami przez Facebook'a, edycja zdjęć, dokumentów tekstowych). To oczywiście nie wszystko: uczestnicy Szkoły @aktywnego Seniora posiadają własną grupę na portalu społecznościowym Facebook, w której wymieniają się swoimi poglądami, zdjęciami i ciekawymi informacjami znalezionymi w Internecie ${ }^{16}$.

Kolejny moduł ma na celu rozwijać pasję tworzenia u ludzi starszych. Wśród uczestników spotkań Szkoły @ktywnego Seniora jest duża grupa osób posiadająca niezwykłe talenty artystyczne i manualne ${ }^{17}$. Z potrzeby tworzenia, co jest to naturalną cechą każdego człowieka, rozpoczęto działania w sferze kulturalnej ludzi starszych. Program Szkoła @ktywnego Seniora zapewnia zaplecze do tworzenia i poznawania kultury oraz aktywizacji, rozwijania pasji i zainteresowań, pozwala wymieniać doświadczenia. Dowodem na twórczą aktywność uczestników Szkoły @ktywnego Seniora są publikacje wydawane wspólnie przez Wojewódzką Bibliotekę Publiczną w Krakowie i Towarzystwo Polsko-Niemieckie w Krakowie. W nich zamieszczone są prace seniorów, będące efektem spotkań w ramach Szkoty @aktywnego Seniora. Działalność artystyczna seniorów to przede wszystkim pisanie wierszy, tekstów prozatorskich, fotografia i malarstwo. Powstał również zespół wokalno-taneczny S@S, w którym to, głównie uczestniczki, mogą realizować swoją pasję śpiewania i tańczenia. Mimo że jest to grupa amatorska, cieszy się niezwykłą popularnością również poza biblioteką. Świadczy o tym wiele zaproszeń na gościnne występy do różnych klubów seniora ${ }^{18}$.

Trzeci moduł ma na celu edukację obywatelską osób starszych. Głównym celem jest wzrost aktywności obywatelskiej środowiska seniorów poprzez stworzenie ramowego programu szkoleń oraz uzyskanie odpowiedniego zainteresowania i wsparcia ze strony władz publicznych. Związku z tym organizowane są odpowiednie warsztaty, seminaria i wykłady dla seniorów i ich trenerów ${ }^{19}$.

${ }^{16}$ Tamże.

17 Młodość $w$ madrości przemijania. Praca zbiorowa uczestników Szkoły @ktywnego Seniora. Pod red. Haliny Stefańskiej-Bursztyńskiej i Wandy MatrasMastalerz. Kraków: Towarzystwo Słowaków w Polsce [etc.], 2008. - ISBN 978-837490-185-7

${ }^{18} \mathrm{Na}$ podstawie rozmowy przeprowadzonej z panią dr Lidią Marią Jedlińską, koordynatorem programu Szkoty@ktywnego Seniora w dniu 3.11.2011 r.

19 Jedlińska, Lidia Maria. Biblioteki kreatorami przyszłości. Nowatorskie rozwiazania Wojewódzkiej Biblioteki Publicznej $w$ Krakowie $w$ stymulowaniu aktywności osób starszych. „Biuletyn EBIB” 2008, nr 7 (98) [dokument elektroniczny]. Dostępny w Internecie: http:// www.ebib.info/2008/98/ a.php?jedlinska [data dostępu: 4.05.2012].

90 


\section{Zrealizowane projekty międzynarodowe i krajowe}

Do projektów krajowych zrealizowanych w ramach Szkoty@aktywnego Seniora należą:

- Szkota @ktywnego Seniora - S@S: edukacja dla kultury dofinansowany przez województwo małopolskie w ramach konkursu „Mecenat Małopolski”

- S@S: senior buszujacy w Sieci dofinansowany przez Fundusz Inicjatyw Obywatelskich (Ministerstwo Pracy i Polityki Społecznej RP).

Ich głównym celem była „aktywizacja osób starszych w dziedzinie kultury i sztuki przy wykorzystaniu metod ICT. Realizowane były głównie poprzez warsztaty, wykłady i kursy komputerowe. Na bazie metod ICT osoby starsze - pod czujnym okiem pracowników krakowskich uczelni - pracowali nad wykorzystaniem własnych subiektywnych przeżyć, biografii w szerszym kontekście"20.

Oprócz projektów krajowych, realizowane były również projekty międzynarodowe: ICT and Inter - Generation Communication (2007-2009), SEVIR - Senior Volunteers in Interest Representations (2007-2008), TeachNET - learning and teaching with seniors and youth (2009-2011), HEuRIT(AGE) (2009-2011). Wszystkie były finansowane przez Komisję Europejską w ramach Programu Partnerskiego Grundtviga „Uczenie się przez całe życie”21.

Pierwszy z nich, ICT and Inter - Generation Communication, był nastawiony na edukację osób starszych w dziedzinie nowych technologii (ICT). Koordynatorem projektu były Czechy, a oprócz Polski wzięły udział takie kraje jak Finlandia, Francja i Niemcy. Celem przedsięwzięcia była pomoc w poszerzaniu wiedzy i umiejętności posługiwania się komputerem, wymiana związanych z tym doświadczeń i wspieranie dialogu międzypokoleniowego. W ramach projektu odbyło się sześć spotkań w miastach krajów partnerskich: w Pradze, Selb, Paryżu, Helsinkach, Monachium i Krakowie, na których dzielono się doświadczeniami odnośnie szkolenia seniorów. Wszystkie pomysły zostały zebrane i przedstawione $\mathrm{w}$ formie multimedialnej $\mathrm{w}$ ramach podsumowania spotkań ${ }^{22}$. Rezultatem działań tego projektu była:

- komputerowa olimpiada seniorów - akcja na skalę europejską;

- międzynarodowe spotkanie seniorów w Krakowie pod patronatem TVP Kraków i Dziennika Polskiego;

\footnotetext{
${ }^{20}$ Tamże.

${ }^{21}$ Tamże.

${ }^{22} \mathrm{Na}$ podstawie rozmowy przeprowadzonej z panią dr Lidią Marią Jedlińską, koordynatorem programu Szkoty @ktywnego Seniora w dniu 3.11.2011 r.
} 
- organizacja I Międzynarodowej Konferencji: „Seniorzy w Nowoczesnym Społeczeństwie Europejskim - nowe technologie w aktywizacji osób starszych" w Krakowie;

- wymiana doświadczeń i materiałów szkoleniowych między trenerami studentami z Czech;

- powstanie dwóch książek napisanych przez seniorów: „Młodość w mądrości przemijania” oraz „Kraków w oczach Seniorów”23.

Drugi projekt, SEVIR - Senior Volunteers in Interest Representations, koordynowany przez Niemcy, miał na celu „wygenerowanie instrumentów pozwalających na stworzenie mechanizmu prowadzącego do aktywnego udziału seniorów i ich reprezentacji w życiu publicznym w krajach europejskich oraz na integrację tego środowiska. Zaangażowanie seniorów w życie społeczne ma się opierać na wzięciu ODPOWIEDZIALNOŚCI ZA SIEBIE"24. Wynikiem tego projektu było powstanie pierwszych w Polsce podręczników dla trenerów i seniorów - wolontariuszy chcących zając się edukacją obywatelską wśród starszego pokolenia Polaków. Wykorzystano przy tym doświadczenie kilku państw europejskich. Podręczniki ukazały się w pięciu wersjach językowych i są dostępne on-line na stronie projektu: http://www.sevir.eu ${ }^{25}$.

Program TeachNET - learning and teaching with seniors and youth, który również był koordynowany przez Niemcy i skierowany nie tylko w stronę seniorów, ale również do młodych ludzi - nauczycieli. Jego zadaniem było „wypracowanie specjalnej oferty edukacyjnej dla nauczycieli prowadzących zajęcia z seniorami i dostosowane do uczestników grupy docelowej oryginalne metody ćwiczeń, oraz indywidualne wsparcie w trakcie nauki, które spowodowało skuteczniejsze opanowanie przez nich wiedzy, jak i również wspieranie młodych nauczycieli $\mathrm{w}$ planowaniu i prowadzeniu szkoleń oraz opracowaniu skutecznych metod treningowych będących rezultatem współpracy seniorów i trenerów"26. W projekcie uczestniczyły, oprócz Polski, Finlandia i Francja.

Realizacja tych celów obejmowała seniorów, nauczycieli i organizacje (w przypadku Polski - biblioteki). Wynikiem działań była:

- organizacja spotkań międzynarodowych;

- wdrożenie nowych metod nauczania;

${ }^{23}$ Szkoła @ktywnego Seniora - strona domowa [online]. Dostępny w Internecie: http://www.sas.tpnk.org.pl/ [data dostępu: 4.05.2012].

${ }^{24}$ Tamże.

${ }^{25}$ Tamże.

${ }^{26}$ Tamże. 
- organizacja III i IV Międzynarodowej Komputerowej Olimpiady Seniorów;

- przeprowadzenie seminariów dla seniorów w celu promowania idei „kształcenia ustawicznego”;

- przeprowadzenie seminariów dla bibliotekarzy Województwa Małopolskiego z zakresu promocji Szkoły @ktywnego Seniora jako dobrej praktyki oraz poszerzenia wiedzy z metod pracy z osobami starszymi;

- przygotowanie do druku książki „Małopolska w naszej pamięci i fotografii" redagowanej przez uczestników Szkoty @ktywnego Seniora (w wersji polskiej i angielskiej);

- organizację II Międzynarodowej Konferencji „Seniorzy w Nowoczesnym Społeczeństwie Europejskim: nowe technologie - moda czy konieczność ${ }^{27}$.

Czwartym projektem był HEuRIT(AGE). Realizacja tego przedsięwzięcia rozpoczęła się od specjalnej wizyty przygotowawczej zorganizowanej przez Towarzystwo Polsko - Niemieckie w Krakowie. W tym spotkaniu uczestniczyli przedstawiciele następujących krajów: Belgia, Czechy, Cypr, Francja, Portugalia, Węgry, Wielka Brytania, Włochy oraz Polska. Koordynatorem inicjatywy była Belgia. Za cel podano „ocalenie od zapomnienia indywidualnych wspomnień, wydarzeń, losów ludzi, umacnianie europejskiej tożsamości" 28 .

Jak można zauważyć, realizacja projektów międzynarodowych przyniosła wiele korzyści nie tylko seniorom, ale również ich trenerom. Biblioteka stała się w ten sposób miejscem dialogu międzypokoleniowego i międzykulturowego. Seniorzy mogli dzięki nim potkać się wirtualnie (przez Skype'a) i realnie ze swoimi rówieśnikami z innych krajów europejskich. Ponadto programy te uzyskały wyróżnienie i uznanie przez Narodową Agencję za przykład dobrej praktyki. Wyniki działań zmuszają do refleksji nad sposobami pracy z seniorami.

\section{Szkoła@aktywnego Seniora dzisiaj i moje doświadczenia}

Od listopada 2011 roku osobiście uczestniczę w niektórych zajęciach organizowanych przez Szkotę @ktywnego Seniora. Wspólnie z seniorami brałem udział w cotygodniowych zajęciach tańca w kręgu, sekcji redakcyjnej, okolicznościowych wykładach i występach grupy artystycznej S@S. Była to forma obserwacji czynnej.

\footnotetext{
${ }^{27}$ Tamże.

${ }^{28}$ Tamże.
} 
Bardzo ciekawe $\mathrm{i}$ godne uwagi są wtorkowe zajęcia $\mathrm{z}$,tańca w kręgu". Ta forma ruchu jest bardzo przyjazna seniorom, gdyż nie wymaga wysokiej sprawności fizycznej i ruchowej. „Tańce w kręgu” oparte są na bardzo prostych, powtarzających się krokach. Ruchy nie muszą być wykonywane perfekcyjne - chodzi tutaj przede wszystkim o integrację z grupą i akceptację swoich niedoskonałości. Z rozmowy, jaką odbyłem z prowadzącą zajęcia, panią mgr Mają Strzelecką wynika, że seniorzy bardzo lubią taniec w kręgu, gdyż ,stawia on każdego na równi - energia i uwaga płynie po kręgu, nikt nie jest poza nim. Stanowi integrację własnych ruchów i grupowych"29.

Rozmawiałem również $\mathrm{z}$ seniorami uczestniczącymi w tańcu. Jedna z pań podzieliła się ze mną swoimi spostrzeżeniami na temat tych zajęć. Stwierdziła, że „»taniec w kręgu« pozwolił jej odzyskać utracony wdzięk. Uruchamia sferę wyobraźni i daje odwagę, aby poczuć się młodo. Ćwiczy giętkość, lekkość w codziennym życiu, ułatwia komunikację (»otwiera« i ośmiela seniorów) ${ }^{\prime 30}$. Pomimo, że zajęcia trwały tylko godzinę, to po nich wszyscy uczestnicy (razem ze mna) czuli się zadowoleni, weseli i szczęśliwi.

Po tańcu w kręgu odbywały się zajęcia z sekcji redakcyjnej. Na nich seniorzy spotykali się i przygotowywali wspólnie materiał do książek, o których już wcześniej wspominałem. Potem były to spotkania, na których rozmawiali i dyskutowali na różne tematy. Seniorki w ramach sekcji przygotowywały się do Międzypokoleniowego Ringu Literackiego realizowanego w oparciu o projekt dofinansowany ze środków Ministra Kultury i Dziedzictwa Narodowego „Zapomniana książka”31. Dnia 24 kwietnia 2012 roku w Ringu udział wzięły dwie grupy uczniów krakowskich szkół: Liceum Ogólnokształcącego nr 27 i Zespołu Państwowych Szkół Plastycznych oraz panie ze Szkoły @ktywnego Seniora. Tematem dyskusji była literatura dla dziewcząt na podstawie książek: Godzina pasowej róży, Szkoła narzeczonych Marii Krüger i Tabliczka marzenia Haliny Snopkiewicz ${ }^{32}$. Rozmowa była bardzo ciekawa, stanowiła idealny przykład dialogu międzypokoleniowego.

${ }^{29}$ Na podstawie rozmowy przeprowadzonej z panią mgr Mają Strzelecką, w dniu 20.03.2012 r.

$30 \mathrm{Na}$ podstawie rozmowy przeprowadzonej z jedną $\mathrm{z}$ uczestniczek Szkoły @ ktywnego Seniora, w dniu 20.03.2012 r.

31 Zapomniana ksiażka. Telewizja Polska SA. [online]. Dostępny w Internecie: http://www.tvp.pl/krakow/patronaty/zapomniana-ksiazka/6959039 [data dostępu: 4.05.2012].

${ }^{32}$ Będkowska A.: Ring Literacki. Wojewódzka Biblioteka Publiczna w Krakowie. [online]. Dostępny w Internecie: http://www.rajska.info/wydarzenia/992-ringliteracki.html [data dostępu: 4.05.2012]. 
W ramach cyklu „PodróżujeMY” zorganizowano wykład jednej z uczestniczek na temat Parku Narodowego Yellowstone. To spotkanie cieszyło się wielkim zainteresowaniem zarówno ze strony seniorów jak i ludzi młodych.

Sekcja artystyczna skupia seniorów, którzy wspólnie wykonują różne ozdoby z papieru, bibuły i materiału. Ta ,plastyczna” aktywność jest również pretekstem do wspólnej rozmowy. W ramach sekcji działa również zespół wokalno-taneczny, o którym wcześniej już wspominałem. Na występy przychodzi duża liczba osób, co świadczy o wielkiej popularności zespołu. Łamie on wszelkie stereotypy pokazując innym, że człowiek może cieszyć się życiem również w późnym wieku.

Od czerwca 2012 roku realizowany jest nowy program dofinansowany z Funduszu Inicjatyw Obywatelskich o nazwie Radość (z) tworzenia w Szkole @ktywnego Seniora, przewidujący stworzenie przez seniorów za pomocą metod ICT kalendarza Szkoty @ktywnego Seniora na 2013 rok. Zadanie będzie poprzedzone licznymi wycieczkami z przewodnikiem po Krakowie.

\section{Podsumowanie}

Zaprezentowane działania Wojewódzkiej Biblioteki Publicznej w Krakowie aktywizujące osoby starsze pokazują jak wielką rolę ma do spełnienia biblioteka. Jej zadaniem jest nie tylko zapewnienie miejsca, ale również wsparcie w postaci zaangażowania wolontariuszy, którzy pracują z seniorami. Wciąż rosnąca liczba uczestników Szkoty @ktywnego Seniora dowodzi, jak bardzo konieczne są takie działania. Aktywny senior nie myśli o swoich niedoskonałościach związanych z wiekiem, lecz cieszy się życiem i ma poczucie akceptacji społecznej.

$$
* * *
$$

Na koniec chciałbym serdecznie podziękować następującym osobom: pani dr Lidii Marii Jedlińskiej za wielką pomoc i wsparcie w pisaniu zarówno pracy licencjackiej oraz niniejszego referatu, a także pani mgr Mai Strzeleckiej za pokazanie, czym jest „magia tańca”. Przede wszystkim chciałbym podziękować seniorom ze Szkoty @ktywnego Seniora, którzy udowodnili, że starość nie jest „chorobą”, a tylko nowym etapem w życiu człowieka, który może wciąż realizować swoje pasje i zainteresowania.

\section{Bibliografia}

1. Augustyn R., Fijał M.: Senior buszujacy w bibliotece. „Biuletyn EBIB” 2008, nr 7 (98) [dokument elektroniczny]. Dostępny w Internecie: http://www.ebib.info/ 2008/98/a.php?augustyn_fijal [data dostępu: 4.05.2012] 
2. Będkowska A.: Ring Literacki. Wojewódzka Biblioteka Publiczna w Krakowie [online]. Dostępny w Internecie: http://www.rajska.info/ wydarzenia/992-ringliteracki.html [data dostępu: 4.05.2012]

3. Dobrowolska M.: Seniorzy $w$ bibliotekach publicznych: poradnik. Warszawa: Wydawnictwo Stowarzyszenia Bibliotekarzy Polskich, 2012. - ISBN 978-8361464-58-7

4. Jedlińska L. M.. Społeczny wymiar działalności nowoczesnej biblioteki. „Es.O.Es” 2007, nr 3, s. 12-15

5. Jedlińska L. M.: Biblioteki kreatorami przyszłości. Nowatorskie rozwiazania Wojewódzkiej Biblioteki Publicznej w Krakowie w stymulowaniu aktywności osób starszych. „Biuletyn EBIB” 2008, nr 7 (98) [dokument elektroniczny]. Dostępny w Internecie: http://www.ebib.info/2008/98/a.php?jed-linska [data dostępu: 4.05.2012]

6. Małopolska $w$ naszej pamięci i fotografii. Praca zbiorowa uczestników Szkoły @ktywnego Seniora. Pod red. Katarzyny Tobolewskiej. Kraków: Towarzystwo Słowaków w Polsce, 2011. ISBN 978-83-60100-33-2

7. Młodość w mądrości przemijania. Praca zbiorowa uczestników Szkoły $@$ @tywnego Seniora. Pod red. Haliny Stefańskiej-Bursztyńskiej i Wandy MatrasMastalerz. Kraków: Towarzystwo Słowaków w Polsce [etc.], 2008. ISBN 978-837490-185-7

8. Redakcja czas-seniora.pl. Stereotypy dotyczace seniorów [online]. Dostępny w Internecie: http://www.czas-seniora.pl/?p=1596 [data dostępu: 4 maja 2012]

9. SEVIR Senior volunteers in interest representations - strona domowa [online]. Dostępny w Internecie: http://www.sevir.eu [data dostępu: 4.05.2012]

10. Skoczkowa E.: Koncepcja działań bibliotek publicznych na rzecz osób starszych $i$ niepetnosprawnych. [online]. Dostępny w Internecie: http://www.znak. org.pl/biblioteka/?sciezka-seniorzy,19 [data dostępu: 4.05.2012]

11.Szkoła @ktywnego Seniora - strona domowa [online]. Dostępny w Internecie: http://www.sas.tpnk.org.pl [data dostępu: 4.05.2012]

12. Woźniakiewicz J.: Regionalne Centrum Integracji Społecznej. Wojewódzka Biblioteka Publiczna w Krakowie. [online]. Dostępny w Internecie: http://www.rajska.info/dla-czytelnikow/regionalne-centrum-integracji-spolecznej. html [data dostępu: 4.05.2012]

13. Zapomniana ksiażka. Telewizja Polska SA. [online]. Dostępne w Internecie: http://www.tvp.pl/krakow/patronaty/zapomniana-ksiazka/6959039 [data dostępu: 4.05.2012] 